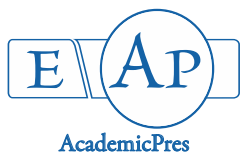

Aladejana OM et al. (2020)

Notulae Scientia Biologicae 12(1):154-171

DOI: $10.15835 / \mathrm{nsb} 12110521$

Research Article

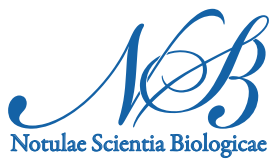

\title{
Production, purification and characterization of thermostable alpha amylase from Bacillus subtilis Y25 isolated from decaying yam (Dioscorea rotundata) tuber
}

\author{
Oluwatoyin M. ALADEJANA ${ }^{1}$, Olaoluwa OYEDEJI ${ }^{2 *}$, \\ Olumide O. OMOBOYE ${ }^{2}$, Mufutau K. BAKARE ${ }^{2}$
}

\author{
${ }^{1}$ Kings University, Faculty of Science, Department of Biological Sciences, Ode Omu, Nigeria; om.aladejana@kingsuniversity.edu.ng \\ ${ }^{2}$ Obafemi Awolowo University, Faculty of Science, Department of Microbiology, Ile-Ife, \\ Nigeria;laoluoyedeji@gmail.com (*correspondingauthor);lummienucleus@yahoo.com; mufubakare@yahoo.com
}

\begin{abstract}
Amylases have wide biotechnological potentials for applications in various industries. An $\alpha$-amylaseproducing bacterium was isolated from deteriorating yam tubers. Molecular characterization using the $16 \mathrm{~S}$ rRNA gene sequencing was used to confirm the identity of the bacterium as Bacillus subtilis Y25. The effect of some cultural and nutritional factors such as $\mathrm{pH}$, temperature, carbon and nitrogen sources on $\alpha$-amylase production from the bacterium was determined. Maximum $\alpha$-amylase production was observed using starch and peptone as carbon and nitrogen sources, respectively, with an initial medium $\mathrm{pH}$ of 8.0 and incubation at $45^{\circ} \mathrm{C}$ for $36 \mathrm{~h}$. The enzyme was purified by ion exchange chromatography on CM Sepharose CL-6B. The kinetic parameters $\mathrm{K}_{\mathrm{m}}$ and $\mathrm{V}_{\max }$ of the enzyme, as well as the effect of $\mathrm{pH}$, temperature, metal ions and ethylenediaminetetra acetic acid (EDTA) on the activity of the purified enzyme were studied. The specific activity of the partially purified enzyme was determined to be $15.21 \mathrm{Units} / \mathrm{mg}$ protein with a purification fold of 3.80. The molecular weight of the purified enzyme was estimated to be $58.0 \mathrm{kDa}$. The $V_{\max }$ and $\mathrm{K}_{\mathrm{m}}$ values obtained with soluble starch for Bacillus subtilis Y25 $\alpha$-amylase were $314.10 \pm 23.30$ Units $/ \mathrm{mg}$ protein and $53.98 \pm 12.03 \mathrm{mg} / \mathrm{ml}$, respectively. The enzyme exhibited optimum activity at a temperature of $60^{\circ} \mathrm{C}$ and $\mathrm{pH}$ 8.0. The metal ion $\mathrm{Ca}^{2+}$ had no effect on the enzyme at $20 \mathrm{mM}$ concentration, whereas $\mathrm{Na}^{+}$and $\mathrm{Mg}^{2+}$, as well as EDTA inhibited the enzyme at the same concentration. The characteristics of the $\alpha$-amylase from Bacillus subtilis Y 25 revealed it to be a thermostable and an alkaline metalloenzyme with potential for applications in the detergent and saccharification industries.
\end{abstract}

Keywords: $\alpha$-amylase; Bacillus subtilis; characterization; optimization; starch; thermostable

\section{Introduction}

Amylases are industrially important enzymes representing about $65 \%$ of the world enzyme market (Reddy et al., 2003; Azad et al., 2009; Elmansy et al., 2018). They are important enzymes that catalyse the breakdown of starch molecules, to give diverse products including dextrin and progressively smaller polymers 
composed of glucose units (Gupta et al., 2003). Two important groups of amylases are $\alpha$-amylases [EC 3.2.1.1] which catalyse the endo-hydrolysis of 1,4- $\alpha$-d-glycosidic linkages between adjacent glucose units inside the linear amylose units (Castro et al., 2010) and $\beta$-amylases [EC 3.2.1.2], which catalyse the hydrolysis of the second $\alpha-1,4$-glycosidic linkages in polysaccharides, thereby removing successive maltose (two glucose units) units from the non-reducing ends of the chains (Bijttebier et al., 2008).

The $\alpha$-amylases are widely distributed in nature and can be derived from various sources, such as plants, animals and microorganisms (Omemu et al., 2005). However, fungi and bacteria are used for commercial production of amylases because of their reliability, ease of manipulation and economic bulk production capacity (Khan and Yadav, 2011; Mathew et al., 2016; Singh et al., 2016). They also involve the expenditure of lesser time, space and cost for production. They have potential for several biotechnological applications in diverse industries such as the food, pharmaceutical, cosmetics, fermentation, textile and paper industries (Pandey et al., 2000; Konsoula and Liakopoulou-Kyriakides, 2007). Other applications are in detergent formulations in detergent industries for removal of tough stains (Mitidieri et al., 2006; Souza and Magalhaes, 2010) and in medicine for clinical diagnosis of several medical conditions (Das et al., 2011).

The performance, economics and feasibility of each $\alpha$-amylase application is influenced by important enzyme characteristics including specificity, stability and optimal temperature and $\mathrm{pH}$ value dependence (Gupta et al., 2003). The selection of suitable microbial strains which produce enzymes exhibiting good activity and stability at industrially desirable conditions is therefore important (Wanderley et al., 2004). Among the bacteria species, the genus Bacillus have been explored for commercial production of $\alpha$-amylases (Konsoula and Liakopoulou-Kyriakides, 2007). These include B. subtilis, B. licheniformis, B. stearothermophillus and B. amyloliquefaciens. Bacillus sp. are the organisms of choice because of their ubiquitous nature, non-fastidious nutritional requirement and ability to overproduce amylase (Sivaramakrishnan et al., 2006).

As most industrial processes are carried out under harsh physicochemical conditions which may not be specifically adjusted to the optimal points required for the activity of the available enzymes, the development of enzymes exhibiting optimal activities at various ranges of salt concentrations, $\mathrm{pH}$ and temperature is of significance. For instance, thermostability is a desirable characteristic of amylases because enzymatic liquefaction and saccharification of starch are performed at high temperatures. Therefore, thermostable amylolytic enzymes are being investigated as agents to improve industrial processes of starch degradation for production of valuable products such as glucose, dextrose syrup, maltose and maltodextrins (Gomes et al., 2003; Asgher et al., 2007).

The present study was therefore designed to explore for amylolytic bacteria from decaying yam (Dioscorea rotundata) tubers and evaluate $\alpha$-amylase production from the selected bacterium under different nutritional and environmental conditions. Subsequent purification and characterization of the enzyme were then carried out to determine its potential for biotechnological and industrial applications.

\section{Materials and Methods}

\section{Collection of decaying yam tubers}

Yam (Dioscorea rotundata) tubers, at different stages of decay, were collected from the yam stalls at the Central Market, Ile-Ife, Osun State, Nigeria. They were placed in sealed cellophane bags and transported to the laboratory, where bacterial isolations were carried out immediately. 


\section{Isolation and maintenance of bacteria}

A sterile scalpel was used to cut into, and remove decayed portions of the yam, which were crushed with sterile mortar and pestle. Five grams of the sample were reconstituted in $45 \mathrm{ml}$ sterile distilled water and serially diluted up to $10^{-6}$. One millilitre of the dilution was plated on nutrient agar and the culture was incubated at $30{ }^{\circ} \mathrm{C}$ for $24 \mathrm{~h}$. Distinct bacterial colonies were purified twice on sterile nutrient agar plates by resuspension in sterile distilled water and plating on the medium. Colonies were then subculture on sterile nutrient agar slants and maintained in the refrigerator at $4{ }^{\circ} \mathrm{C}$.

\section{Screening of bacteria for a-amylase production}

The bacterial isolates were screened for amylolytic activity using the starch hydrolysis test on starch agar plate. Each of the bacteria strains was streaked on separate starch agar plate and incubated for $30{ }^{\circ} \mathrm{C}$ for $48 \mathrm{~h}$. After incubation, the starch agar plates were flooded with Grams' iodine solution. The clear zones around the colonies were suggestive of amylase production. The diameter of the zones of clearing was measured and the bacterium with the largest zone of clearance was selected for further studies.

\section{Molecular characterization and identification of bacterium}

An overnight culture of the selected bacterium was used for the preparation of genomic DNA. The DNA was isolated using the cetytrimethyl ammonium bromide (CTAB) method. Molecular characterization and identification of the bacterium was carried out by the $16 \mathrm{~S}$ rRNA gene sequencing using universal primers (El-Helow, 2001). The forward and reverse primers were of the following sequences, respectively: 27f (5'AGAGTTTGATCMTGGCTCAG-3') and 1492R (5'-ACCTTGTTACGACTT-3'). The PCR was carried out for $94^{\circ} \mathrm{C}$ for $3 \mathrm{~min}$, followed by 30 cycles of $94^{\circ} \mathrm{C}$ for $60 \mathrm{sec}, 56^{\circ} \mathrm{C}$ for $60 \mathrm{sec}, 72{ }^{\circ} \mathrm{C}$ for $120 \mathrm{sec}$ and final extension temperature of $72^{\circ} \mathrm{C}$ for $5 \mathrm{~min}$ and the $4^{\circ} \mathrm{C}$ hold forever. After completion, a fraction of the PCR mixture was examined using agarose gel electrophoresis and the DNA was visualized using the ultraviolet transilluminator. The $16 \mathrm{~S}$ rRNA gene fragment of the bacterium was sequenced in both direction and Blast program (https://blast.ncbi.nlm.nih.gov/Blast.cgi) was used to assess the DNA similarities. Phylogenetic tree for the bacterium was constructed using the Neighbor-joining method with 1000 bootsrap replication (Tamura et al., 2013) and Bacillus anthracis 2000031650 was used as the outgroup. Evolutionary relationship with other Bacillus sp. in the GenBank was conducted in Molecular Evolutionary Genetics Analysis (MEGA) version 6.0.

\section{Enzyme production conditions}

Amylase production was carried out in $250 \mathrm{ml}$ Erlenmeyer flask containing $100 \mathrm{ml}$ medium using $1 \mathrm{ml}$ $0.5 \mathrm{McF}$ arland standard inoculum. One liter of the medium contained $1 \mathrm{~g}$ soluble starch, $0.1 \mathrm{~g} \mathrm{KH}_{2} \mathrm{PO}_{4}, 0.25$ $\mathrm{g} \mathrm{Na}_{2} \mathrm{HPO}_{4}, 0.1 \mathrm{~g} \mathrm{NaCl} 0.005 \mathrm{~g} \mathrm{MgSO}_{4} .7 \mathrm{H}_{2} \mathrm{O}, 0.005 \mathrm{~g} \mathrm{CaCl}_{2}, 0.2 \mathrm{~g}\left(\mathrm{NH}_{4}\right)_{2} \mathrm{SO}_{4}$ and $0.2 \mathrm{~g}$ peptone; at $\mathrm{pH}$ 8.0. The culture was incubated at $45^{\circ} \mathrm{C}$ for $48 \mathrm{~h}$ with a steady agitation at $150 \mathrm{rpm}$. After incubation, the culture was centrifuged at $6,000 \mathrm{rpm}$ for $30 \mathrm{~min}$ and the cell free supernatant used for $\alpha$-amylase activity determination.

\section{Determination of $a$-amylase activity}

$\alpha$-Amylase activity was determined by using the method of Somogyi (1952). One milliliter reaction mixture contained $0.1 \mathrm{ml}$ of $1.0 \%(\mathrm{w} / \mathrm{v})$ gelatinized starch in $0.85 \mathrm{ml}$ of $10 \mathrm{mM}$ tris buffer, $\mathrm{pH} 8.0$ and 0.05 $\mathrm{ml}$ of crude enzyme. The mixture was shaken and then incubated at $50{ }^{\circ} \mathrm{C}$ for $20 \mathrm{~min}$. The reaction was terminated by the addition of $1.0 \mathrm{ml}$ combined copper reagent. The reaction mixture was boiled for $20 \mathrm{~min}$ and then cooled. This was followed by addition of $1.0 \mathrm{ml}$ of arsenomolybdate reagent while shaking. The solution was made up to $10 \mathrm{ml}$ with $7.0 \mathrm{ml}$ distilled water and the absorbance read at $540 \mathrm{~nm}$ against the blank which consisted of all the assay components except the enzyme. One unit of $\alpha$-amylase is defined as the 
amount of enzyme that released $1.0 \mu \mathrm{g}$ of glucose equivalence from the substrate per millilitre per minute under the specified assay condition. Protein concentration was determined by the method of Bradford (1976), using bovine serum albumin as the standard protein.

\section{Growth pattern and enzyme production}

The bacterium growth pattern and $\alpha$-amylase production were determined by inoculating a $250 \mathrm{ml}$ enzyme production medium with $10 \mathrm{ml}$ standard inoculum of $0.5 \mathrm{McF}$ arland standard in an Erlenmeyer flask. This was incubated at $45^{\circ} \mathrm{C}$ for $48 \mathrm{~h}$ with agitation at $150 \mathrm{rpm}$. At $2 \mathrm{~h}$ intervals, $5 \mathrm{ml}$ samples were aseptically sampled for a period of $48 \mathrm{~h}$ and the growth was checked at $680 \mathrm{~nm}$ using Spectrumlab 23A spectrophotometer and recorded as the cell optical density. Also, the $\alpha$-amylase activity of each cell-free supernatant sample was determined.

\section{Influence of nutritional and environmental factors on $\alpha$-amylase production \\ Effect of $p H$ on $\alpha$-amylase production}

The effect of $\mathrm{pH}$, in the range of 6.0-8.5, on $\alpha$-amylase production, in $50 \mathrm{ml}$ of production medium was determined. Standardized inoculum $(0.5 \mathrm{ml})$ of bacterium was used and incubation was at $45^{\circ} \mathrm{C}$ for $48 \mathrm{~h}$ with agitation at $150 \mathrm{rpm}$. After incubation, the cells were removed by centrifugation and the cell free supernatant tested for $\alpha$-amylase activity.

\section{Effect of temperature on a-amylase production}

The optimum temperature for $\alpha$-amylase production was determined by varying incubation temperature of the culture medium from 30 to $50^{\circ} \mathrm{C}$, at $\mathrm{pH} 8.0$ for $48 \mathrm{~h}$ with agitation at $150 \mathrm{rpm}$. The cells were then removed by centrifugation and the amount of $\alpha$-amylase present in supernatant was quantified.

\section{Effect of carbon sources on $\alpha$-amylase production}

The effect of carbon sources on enzyme production was studied by replacing soluble starch $(0.1 \% \mathrm{w} / \mathrm{v})$ with different sugars: glucose, maltose and lactose, while other media components were kept constant. The fermentation medium, previously adjusted to $\mathrm{pH} 8.0$, was inoculated with $0.5 \mathrm{ml}$ cell suspension and the culture incubated for $48 \mathrm{~h}$ at $50^{\circ} \mathrm{C}$ with agitation at $150 \mathrm{rpm}$. The supernatant obtained was then tested for amylolytic activity.

\section{Effect of soluble starch concentration on $\alpha$-amylase production}

The influence of different concentrations of soluble starch $(0.5,1.0,1.5,2.0$ and $2.5 \%, \mathrm{w} / \mathrm{v})$ on $\alpha$ amylase production from bacterium was studied. The culture was incubated for $28 \mathrm{~h}$ at $45^{\circ} \mathrm{C}$ with agitation at $150 \mathrm{rpm}$. The supernatant was obtained and $\alpha$-amylase production determined.

\section{Effect of nitrogen sources on $\alpha$-amylase production}

The production medium $(50 \mathrm{ml})$ was composed with different nitrogen sources which included $\mathrm{Ca}$ $\left(\mathrm{NO}_{3}\right)_{2},\left(\mathrm{NH}_{4}\right)_{2} \mathrm{SO}_{4}$, peptone and tryptic soy broth (TSB). The medium was incubated for $48 \mathrm{~h}$ at $45^{\circ} \mathrm{C}$ with agitation at $150 \mathrm{rpm}$. After incubation, the supernatant obtained was tested for $\alpha$-amylase activity.

\section{Purification of a-amylase}

Purification using ion-exchange chromatography on CM-Sepharose CL-6B

$\alpha$-Amylase was purified from the cell-free supernatant. Ten milliliters of the supernatant obtained from a batch culture was layered on a $1.0 \mathrm{~cm} \times 10 \mathrm{~cm}$ column of CM Sepharose CL-6B which had previously been equilibrated with $10 \mathrm{mM}$ phosphate buffer, $\mathrm{pH}$ 8.0. One milliliter fraction was collected at a flow rate of $12 \mathrm{ml} / \mathrm{h}$ and bound proteins were eluted with a linear gradient of 0 to $1.0 \mathrm{M} \mathrm{NaCl}$. The fractions were 
158

assayed for $\alpha$-amylase activities and the protein profile was determined. Active fractions in the peak were pooled and used for further studies.

\section{Determination of $\alpha$-amylase molecular mass}

The native molecular mass of $\alpha$-amylase from bacterium was determined by gel filtration in sephadex G-100 chromatographic column. Bovine serum albumin $(66 \mathrm{kDa}), \alpha$-chromotrypsinogen A $(25 \mathrm{kDa})$ and Iysozyme $(15 \mathrm{kDa})$ were used as standard proteins.

\section{Determination of kinetic parameter}

Kinetic parameters $K_{m}$ and $V_{\max }$ for the purified $\alpha$-amylase were estimated with soluble starch as substrate, at concentrations $0-200 \mathrm{mg} / \mathrm{ml}$, using the non-linear regressionanalysis software (Graph pad Prism 5).

\section{Effect of temperature on the activity of a-amylase}

The effect of temperature on $\alpha$-amylase activity was studied by incubating an aliquot of the enzyme with the substrate at temperatures ranging from 30 to $90{ }^{\circ} \mathrm{C}$, for 20 mins. Unincubated purified $\alpha$-amylase was used as the control. The residual activities of the enzyme were determined and plotted against the different temperatures.

\section{Thermal stability of purified $\alpha$-amylase from Bacillus subtilis}

Thermal stability of the purified enzyme was examined by incubating the enzyme preparation for 60 min at different temperatures $\left(50\right.$ to $\left.65^{\circ} \mathrm{C}\right)$, in the absence of the substrate. Aliquots were withdrawn at 10 min intervals and the residual enzyme activities were measured under standard assay conditions earlier stated. The residual activities were expressed as a percentage of the activity at zero time which was taken to be $100 \%$. The percentage residual activity was plotted against incubation period.

\section{Effect of $p H$ on the activity of $\alpha$-amylase}

The effect of $\mathrm{pH}$ on $\alpha$-amylase activity was performed in the $\mathrm{pH}$ range of 4.0 to 9.0 , at $45^{\circ} \mathrm{C}$. The following buffer systems at the indicated $\mathrm{pH}$ values were used: $10 \mathrm{mM}$ acetate buffer, $\mathrm{pH}$ 4.0-5.5; $10 \mathrm{mM}$ phosphate buffer, $\mathrm{pH}$ 6.0-7.5 and 10-mM tris buffer, $\mathrm{pH} 8.0$ - 9.0.

\section{Effect of cations and ethylenediamine tetracetic acid (EDTA) on a-amylase activity}

The effect of metal ions on $\alpha$-amylase activity was determined by incubating the enzyme with $\mathrm{NaCl}$, $\mathrm{MgCl}_{2}$ and $\mathrm{CaCl}_{2}$ separately dissolved in the assay buffer at a final concentration of $20 \mathrm{mM}$ each and $\mathrm{pH} 8.0$. The control did not contain the metal ions. The enzyme activity was expressed as a percentage of the control which was taken to be $100 \%$. The effect of ethylenediamine tetraacetic acid (EDTA) on the activity of $\alpha$ amylase was determined by assaying the enzyme in the presence of the $20 \mathrm{mM}$ EDTA. The residual activity was also expressed as a percentage of the control which was taken as $100 \%$.

\section{Results}

\section{Isolation and screening of amylolytic bacteria}

Out of the thirty-six isolates obtained from decaying yam, seven of the isolates showed a zone of clearance around the colonies on starch agar plate. The isolates were labelled Y4, Y22, Y23, Y25, Y31, Y35 and Y36. These isolates were screened for their amylolytic activities under submerged fermentation condition 
using soluble starch as sole source of carbon. Isolate Y25 exhibited the highest activity and was therefore selected for further studies.

\section{Molecular characterization and identification of amylolytic bacterium}

In order to identify the isolate on molecular basis, the 16S rRNA gene from the strain Y25 was amplified and sequenced. The sequence was analyzed using the BLAST analysis and was found to have 100\% homology with several B. subtilis reported from different parts of the world in the data bank of the NCBI (Altschul et al., 1990). Based on the molecular characterization, the strain Y25 was identified as B. subtilis. Phylogenetic analysis revealed a close relationship between the selected bacterial specie and other Bacillus species in the GenBank. However, there was a distant relationship with Bacillus anthracis (Figure 1).

\section{Growth pattern and $\alpha$-amylase production}

The bacterial growth was observed to increase with increase in aamylase activity. The lag phase lasted for about $2 \mathrm{~h}$, while the exponential phase of the growth lasted for $32 \mathrm{~h}$. The $\alpha$-amylase activity of Bacillus

subtilis $\mathrm{Y} 25$ reached its maximum level after $36 \mathrm{~h}$ incubation. Thereafter, there was a decline in the amylase production (Figure 2).

\section{Influence of nutritional and environmental factors on bacterium $\alpha$-amylase production}

The effect of various nutritional and environmental parameters on $\alpha$-amylase production from $B$. subtilis $\mathrm{Y} 25$ was determined.

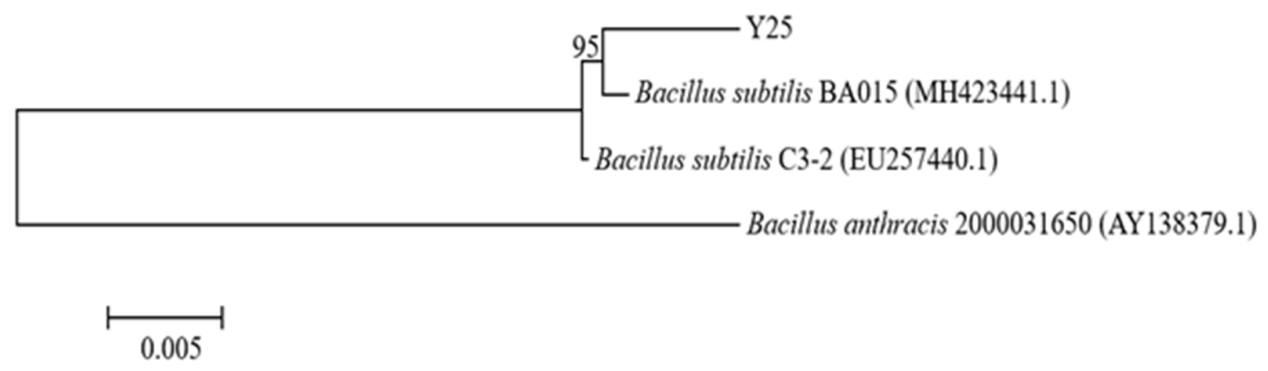

Figure 1. Molecular phylogenetic analysis of $16 \mathrm{~S}$ rRNA gene of $B$. subtilis Y25. The tree was constructed with MEGA 6 (Neighbour Joining method with 1000 bootstrap replication) 
160

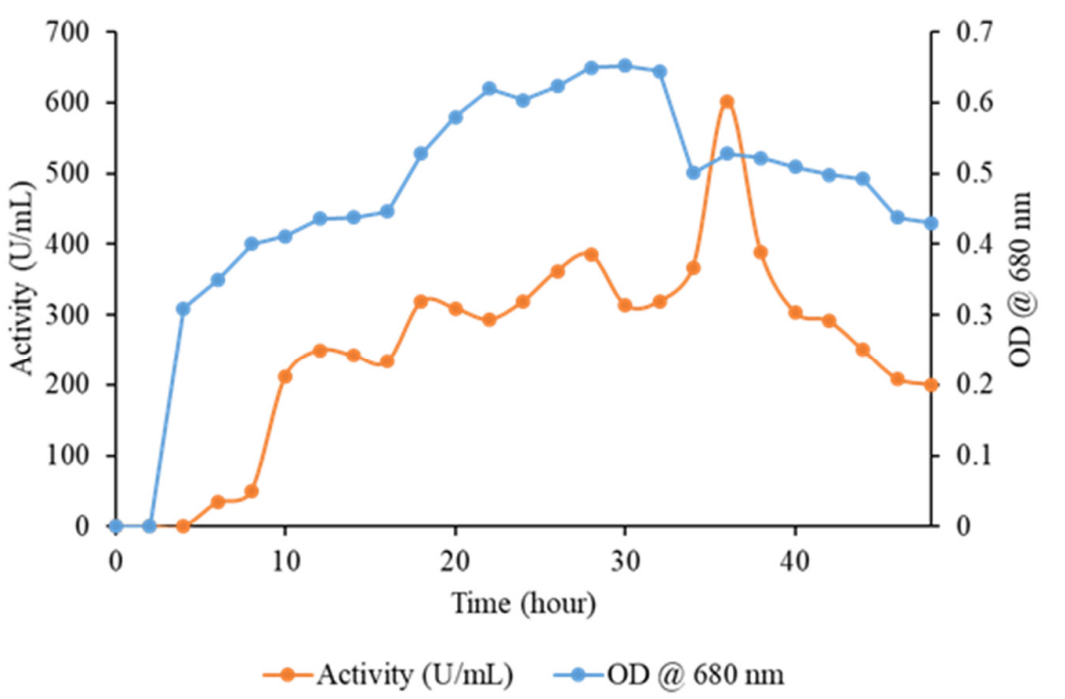

Figure 2. Growth and enzyme production from B. subtilis $\mathrm{Y} 25$ at $45^{\circ} \mathrm{C}$ and $\mathrm{pH} 8.0$ for $48 \mathrm{~h}$.

Effect of $p H$ on $\alpha$-amylase production

The influence of $\mathrm{pH}$, in the range 6.0 to 9.0, on $\alpha$-amylase production and from Bacillus subtilis Y25 was determined. Maximum $\alpha$-amylase production was achieved at $\mathrm{pH} 8.0$ (Figure 3). Thus, the $\mathrm{pH} 8.0$ was selected for maximum production of enzyme.

\section{Effect of temperature on a-amylase production}

Figure 4 shows the effect of various incubation temperature on $\alpha$-amylase production from Bacillus subtilis Y25. Optimum production of $\alpha$-amylase was observed at $45^{\circ} \mathrm{C}$ (Figure 4). Beyond this temperature, enzyme production decreased drastically.

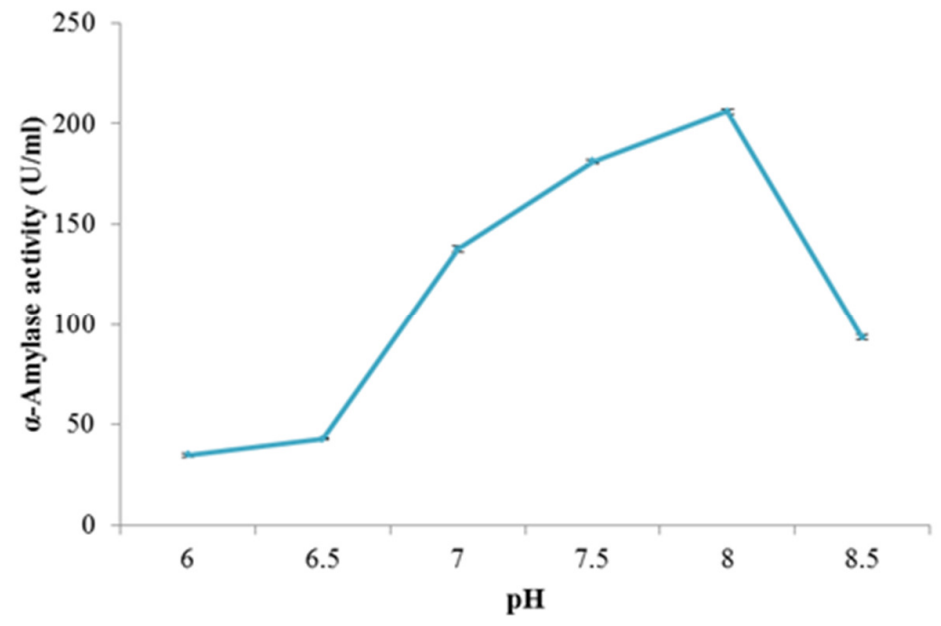

Figure 3. Effect of $\mathrm{pH}$ on $\alpha$-amylase production from B. subtilis $\mathrm{Y} 25$

Values are means \pm standard deviation of three independent experiments used in study 


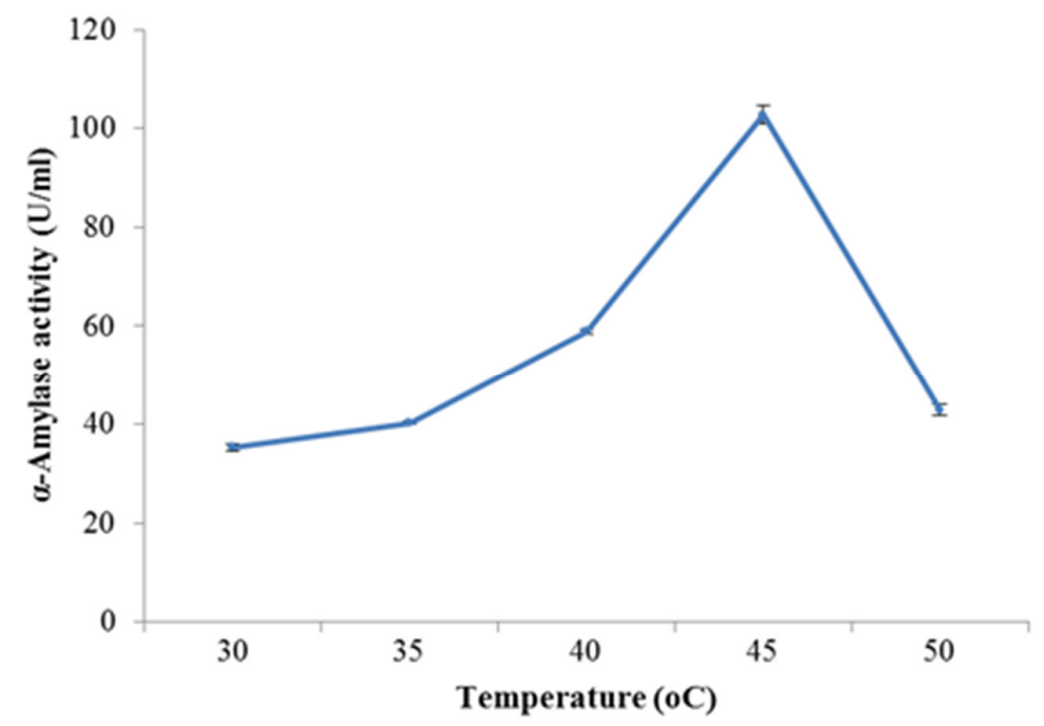

Figure 4. Effect of temperature on $\alpha$-amylase production from B. subtilis $\mathrm{Y} 25$

Values are means \pm standard deviation of three independent experiments used in study

\section{Effect of different carbon and nitrogen sources on $\alpha$-amylase production}

$\alpha$-Amylase production from Bacillus subtilis Y25 was maximum with the use of starch as the source of carbon $(95.25 \pm 2.03 \mathrm{U} / \mathrm{ml})$. This was followed by the use of lactose $(21.29 \pm 1.57 \mathrm{U} / \mathrm{ml})$, glucose $(19.03 \pm 1.36$ $\mathrm{U} / \mathrm{ml}$ ) and maltose $(9.48 \pm 0.93 \mathrm{U} / \mathrm{ml}$ ) as carbon sources, respectively (Figure 5). Maximum production of $\alpha$ amylase from B. subtilis Y25 was observed with the use of peptone as the nitrogen source in the production medium $(49.97 \pm 1.35 \mathrm{U} / \mathrm{ml})$. This was followed by the use of calcium nitrate $(16.65 \pm 1.20 \mathrm{U} / \mathrm{ml})$, tryptic soy broth $(18.02 \pm 0.60 \mathrm{U} / \mathrm{ml})$ and ammonium sulphate $(37.22 \pm 1.09 \mathrm{U} / \mathrm{ml})$ respectively, as sources of nitrogen (Figure 6).

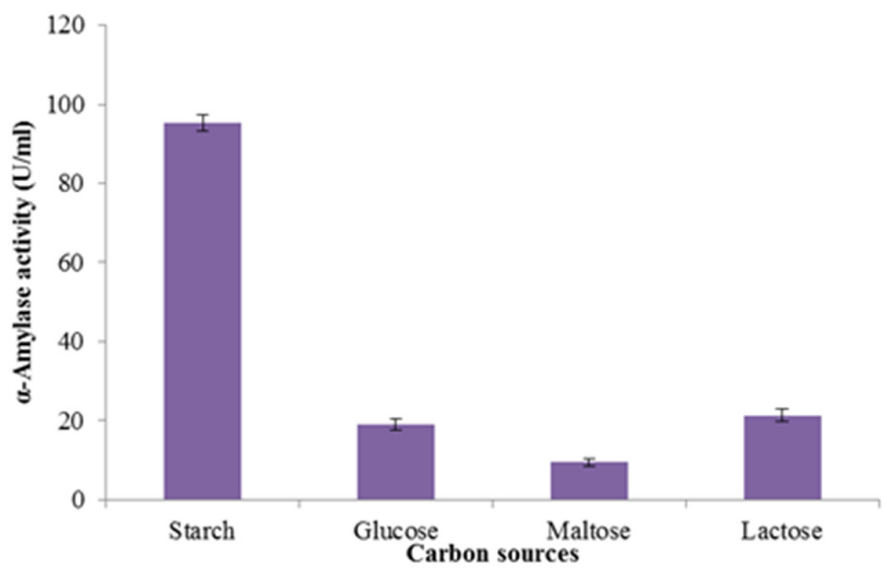

Figure 5. Effect of carbon sources on $\alpha$-amylase production from B. subtilis Y25

Values are means \pm standard deviation of three independent experiments used in study 


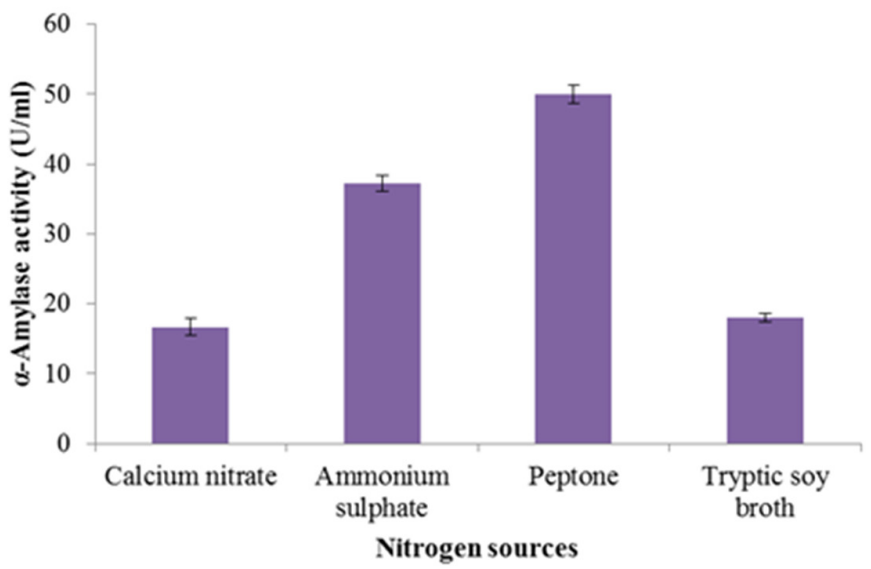

Figure 6. Effect of nitrogen sources on $\alpha$-amylase production from B. subtilis Y25

Values are means \pm standard deviation of three independent experiments used in study

\section{Effect of starch concentration on $\alpha$-amylase production}

The influence of different concentration of starch $(0.5 \%$ to $2.5 \% \mathrm{w} / \mathrm{v})$ in the production medium, on $\alpha$ amylase production from $B$. subtilis Y25, was studied. Maximum production of $\alpha$-amylase was observed at $0.5 \% \mathrm{w} / \mathrm{v}$ starch concentration with activity of $97.85 \pm 1.11 \mathrm{U} / \mathrm{ml}$. However, the enzyme production decreased with increase in starch concentration beyond $0.5 \% \mathrm{w} / \mathrm{v}$ (Figure 7 ).

\section{Enzyme purification and characterization}

Purification of enzyme using ion exchange column chromatography on CM-Sepharose CL-6B

After ion exchange chromatography on CM-Sepharose CL-6B column in which adsorbed proteins were eluted with a linear gradient of 0 to $1.0 \mathrm{M} \mathrm{NaCl}$, active fractions of $\alpha$-amylase from B. subtilis Y25 were pooled. The elution profile is as shown in Figure 8 . The pooled fractions had a specific activity of A single peak of $\alpha$-amylase activity was observed with a yield of $69.36 \%$, specific activity of $112.37 \mathrm{U} / \mathrm{mg}$ protein and purification fold of 3.80 (Figure 8 and Table 1).

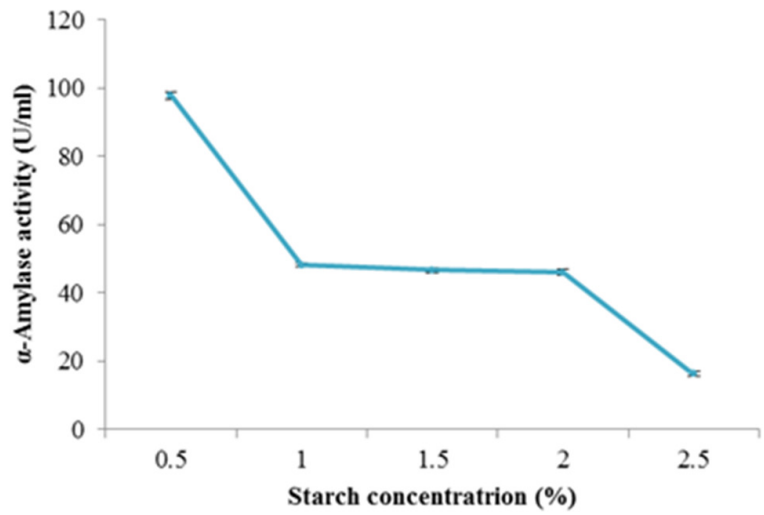

Figure 7. Effect of starch concentration on $\alpha$-amylase production from B. subtilis $\mathrm{Y} 25$

Values are means \pm standard deviation of three independent experiments used in study 


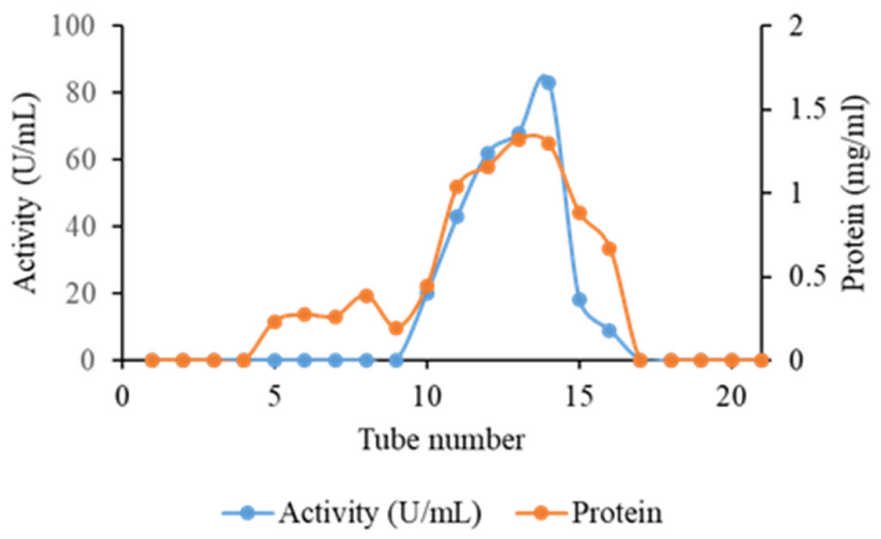

Figure 8. Elution profile of $\alpha$-amylase from B. subtilis Y25 on CM Sepharose CL-6B. The flow rate was $12 \mathrm{ml} / \mathrm{h}$. Bound proteins were eluted with a $0-1 \mathrm{M} \mathrm{NaCl}$ gradient dissolved in the elution buffer. Fractions were assayed for amylase activity and protein profile was assayed

Table 1. Summary of purification steps $\alpha$-amylase obtained from Bacillus subtilis Y25

\begin{tabular}{|c|c|c|c|c|c|c|c|c|}
\hline $\begin{array}{c}\text { Purification } \\
\text { step }\end{array}$ & $\begin{array}{c}\text { Volume } \\
(\mathrm{ml})\end{array}$ & $\begin{array}{c}\text { Activity } \\
(\text { Units/ml) }\end{array}$ & $\begin{array}{c}\text { Total } \\
\text { activity } \\
\text { (Units) }\end{array}$ & $\begin{array}{c}\text { Protein } \\
(\mathrm{mg} / \mathrm{ml})\end{array}$ & $\begin{array}{c}\text { Total } \\
\text { protein } \\
(\mathrm{mg})\end{array}$ & $\begin{array}{c}\text { Specific } \\
\text { activity } \\
(\mathrm{U} / \mathrm{mg})\end{array}$ & $\begin{array}{c}\text { Yield } \\
(\%)\end{array}$ & $\begin{array}{c}\text { Purification } \\
\text { fold }\end{array}$ \\
\hline $\begin{array}{c}\text { Crude } \\
\text { enzyme }\end{array}$ & 135 & 12 & 1620 & 3 & 405 & 4 & 100 & 1 \\
\hline $\begin{array}{c}\text { CM } \\
\text { Sepharose } \\
\text { CL-6B }\end{array}$ & 10 & 112.37 & 1123.7 & 7.39 & 70.39 & 15.21 & 69.36 & 3.8 \\
\hline
\end{tabular}

Molecular mass of $\alpha$-amylase

The native molecular weight of the purified $\alpha$-amylase from Bacillus subtilis Y25 was determined by gel permeation chromatography on Sephadex G-100. The molecular weight was estimated to be 58 KDa.

\section{Kinetic parameter}

The Michaelis-Menten constants $\left(\mathrm{K}_{\mathrm{m}}\right.$ and $\left.\mathrm{V}_{\max }\right)$ of the purified Bacillus subtilis $\mathrm{Y} 25$-amylase for hydrolysis of soluble starch were estimated using Graphpad prism 5 Computer Software Programme to be $53.98 \pm 12.03 \mathrm{mg} / \mathrm{ml}$ and $314.10 \pm 23.30$ Units/mg protein, respectively (Figure 9).

\section{Optimum temperature of a-amylase from B. subtilis}

The effect of temperature on the activity of purified $\alpha$-amylase, in the range 30 to $100{ }^{\circ} \mathrm{C}$, was studied. The enzyme activity increased gradually from $30^{\circ} \mathrm{C}$ to reach the maximum at a temperature of $60^{\circ} \mathrm{C}$. Beyond this optimum temperature, the activity reduced drastically (Figure 10). 


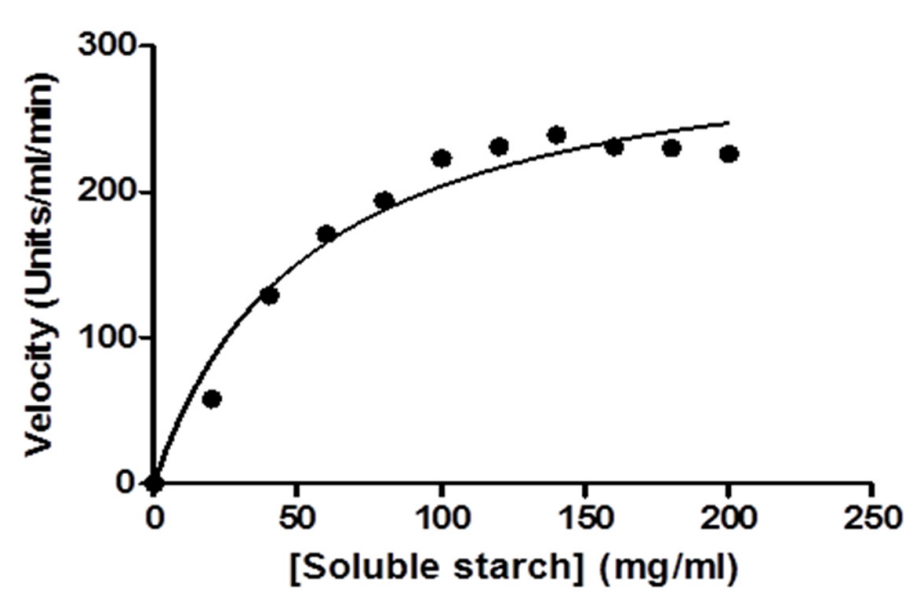

Figure 9. Non-linear regression plot for kinetic parameter of $\alpha$-amylase from B. subtilis Y25 using Graph Pad Prism. Incubation was for $20 \mathrm{~min}$ at temperature of $60^{\circ} \mathrm{C}$ and $\mathrm{pH}$ of 8.0

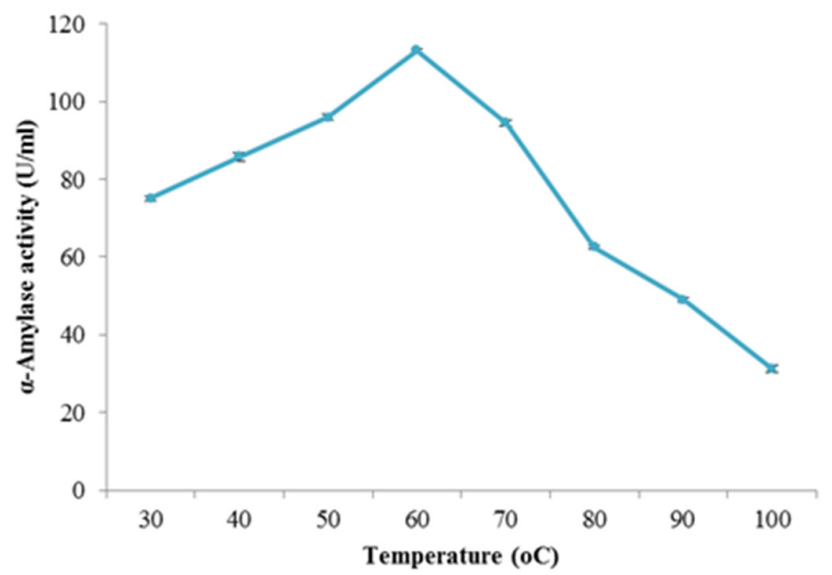

Figure 10. Effect of temperature on the activity of purified $\alpha$-amylase from B. subtilis $\mathrm{Y} 25$

Values are means \pm standard deviation of three independent experiments used in study

\section{Thermal stability of a-amylase from B. subtilis}

The enzyme showed appreciable thermal stability up to $60^{\circ} \mathrm{C}$ retaining $70.39 \%, 56.89 \%$ and $50.44 \%$ of its activity after $30 \mathrm{~min}, 40 \mathrm{~min}$ and $50 \mathrm{~min}$, respectively. However, it was rapidly inactivated at longer periods and at higher temperature (Figure 11).

Optimum $p H$ of $\alpha$-amylase from B. subtilis

The activity of $\alpha$-amylase from $B$. subtilis increased as the $\mathrm{pH}$ increased reaching the optimum at $\mathrm{pH}$ 8.0. The enzyme was observed to exhibit appreciable activity at $\mathrm{pH}$ range 6.0 to 7.5 and very good activity at $\mathrm{pH}$ range 7.0 to 9.0 (Figure 12).

Influence of metal ions and EDTA on a-amylase from B. subtilis $\mathrm{Y} 25$

The effect of metal ions and EDTA on the activity of purified $\alpha$-amylase from Bacillus subtilis Y25 was studied and shown in Table 2 . The enzyme showed great stability against all the tested metal ions $\left(\mathrm{Na}^{+}, \mathrm{Mg}^{2+}\right.$ 
$\left.\mathrm{Ca}^{2+}\right)$, at $20 \mathrm{mM}$ concentration. However, EDTA produced an inhibition effect of $37.0 \%$ on the enzyme activity (Table 2).

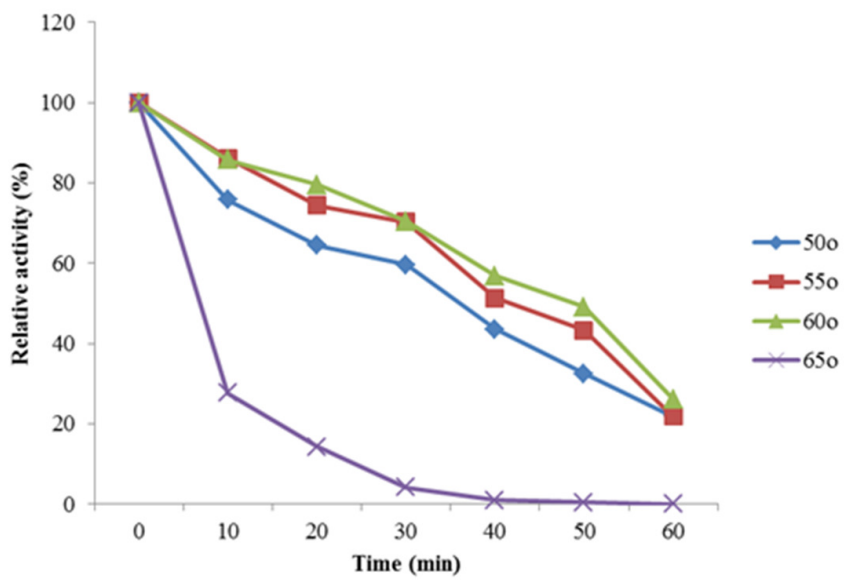

Figure 11. Thermal stability of purified $\alpha$-amylase from Bacillus subtilis Y25

Values are means \pm standard deviation of three independent experiments used in study

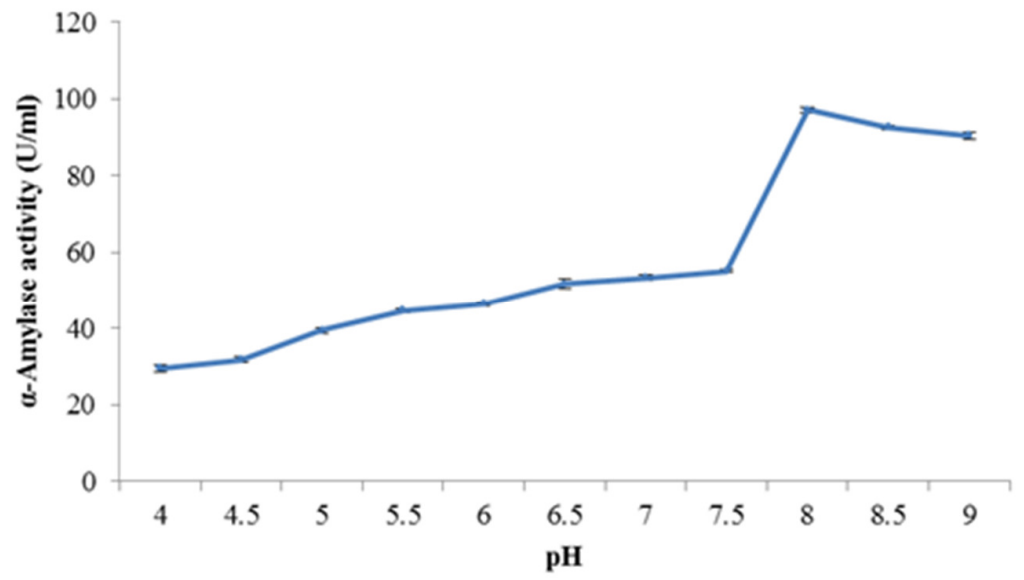

Figure 12. Effect of $\mathrm{pH}$ on the activity of purified $\alpha$-amylase from Bacillus subtilis Y25

Values are means \pm standard deviation of three independent experiments used in study

Table 2. Effect of metal ions and EDTA on the activity of $\alpha$-amylase from B. subtilis Y25

\begin{tabular}{|c|c|c|}
\hline S/No. & Addition & Relative activity (\%) \\
\hline 1 & None (control) & 100 \\
\hline 2 & $\mathrm{NaCl}$ & 83 \\
\hline 3 & $\mathrm{CaCl}_{2}$ & 100 \\
\hline 4 & $\mathrm{MgCl}_{2}$ & 97 \\
\hline 5 & EDTA & 63 \\
\hline
\end{tabular}

\section{Discussion}

In the present study, thirty-six bacterial isolates were obtained from decaying yam tubers and screened for potential $\alpha$-amylase production on starch agar plates. Seven of the isolates expressed $\alpha$-amylase production 
166

by showing zones of clearance around their colonies. Subjection of these to enzyme production and quantitation of their $\alpha$-amylase activities revealed the isolate Y25 as the best enzyme producer. This bacterium was selected for subsequent studies. It was characterized and identified by molecular method, based on the $16 \mathrm{~S}$ rRNA gene sequencing, as a strain of of $B$. subtilis with maximum identity of $100 \%$ to other $B$. subtilis. Several species of bacteria belonging to the genera Bacillus are reported to exhibit the ability for $\alpha$ amylase production (Shalini and Solanki, 2014; Ayansina et al., 2017; Demirkan et al., 2017; Ozdemir et al., 2018).

The production of enzymes such as $\alpha$-amylase is often dependent on growth of the producing bacterium in the appropriate culture medium. In the present study, the $\alpha$-amylase production increased with increase in the incubation period reaching a maximum at $32 \mathrm{~h}$ incubation after which enzyme production declined. The growth pattern followed a similar trend with B. subtilis Y25 having a lag phase of $2 \mathrm{~h}$ and then growing logarithmically from $4 \mathrm{~h}$ to $32 \mathrm{~h}$ with a corresponding increase in enzyme production. The growth peaked at $36 \mathrm{~h}$ of incubation period beyond which a steady decline occurred. A similar pattern of bacterium growth and $\alpha$-amylase production, in relation to incubation period, was reported by Prakash et al. (2008).

The optimum $\mathrm{pH}$ for $B$. subtilis $\mathrm{Y} 25 \alpha$-amylase production was observed to be 8.0. Anupama and Jayaraman (2011) reported a similar $\mathrm{pH}$ for $\alpha$-amylase production from $B$. aquimaris VITP4. However, $\mathrm{pH}$ of 7.0 was reported for $\alpha$-amylase production from strains of several Bacillus species (Mohammed et al., 2011; Singh et al., 2012; Omoboye et al., 2014; Demirkan et al., 2017). Saxena et al. (2007) had reported that $\alpha$ amylase production from Bacillus species mostly occur in alkaline conditions ( $\mathrm{pH} 7.5$ to 11.0). The optimum $\mathrm{pH}$ influences the way the shape of the active site is most complementary to the shape of the substrate. Any change above or below the optimum will quickly cause a decrease in the rate of reaction, since more of the enzyme molecules will have active sites whose shapes are not or at least are less complementary to the shape of their substrate (Demirkan et al., 2017).

Maximum production of $\alpha$-amylase occurred at a temperature of $45^{\circ} \mathrm{C}$ beyond which there was decline in enzyme production. A similar incubation temperature was best for the enzyme production from $B$. licheniformis RD24 (Omoboye et al., 2014) and B. cereus Ms6 (Mohammed et al., 2011). However, optimum temperature of $40{ }^{\circ} \mathrm{C}$ was reported for $\alpha$-amylase production from several other Bacillus species (Konsoula and Liakopoulou-Kyriakides, 2004; Mukhtar and Ikram, 2012; Singh et al., 2015). At high temperatures, enzyme production decreased which might be due to growth inhibition and hence enzyme inactivation (Goes and Sheppard, 1999).

Alpha amylase production from Bacillus subtilis Y25 was maximum with the use of starch as the carbon source, followed by the use of lactose, glucose and maltose, respectively. Elkady et al. (2017) and Gangadharan et al. (2006) reported that Bacillus sp. NRC12017 and Bacillus amyloliquefaciens, respectively, gave the highest enzyme yield with soluble starch. A decrease in enzyme production was observed with an increase in starch concentration. This is similar to the report of Elmansy et al. (2018). High starch concentrations cause the broth culture to be more viscous, thus interfering with $\mathrm{O}_{2}$ transfer resulting in restriction of dissolved $\mathrm{O}_{2}$ required for the microbial growth. Maximum production of $\alpha$-amylase from $B$. subtilis $\mathrm{Y} 25$ was observed with the use of peptone as the nitrogen source in the production medium. This may be due to the fact that peptone is readily available to the bacterium for metabolism during growth and enzyme production as opposed to other nitrogen sources. Nitrogen source type and relative concentration in the growth medium are important for both microbial growth and amylase production (NandLal et al., 2016). The nitrogen is metabolized to produce primarily amino acids, nucleic acids, protein, enzymes and other cellular components that play a vital role in metabolism. Purification using ion exchange chromatography through CM-Sepharose CL-6B gave a specific activity $1123.7 \mathrm{U} / \mathrm{mg}$ protein and yield of $69.36 \%$ with purification fold of 3.80. Abdel-Fattah et al. (2012) and Bakare et al. (2014) indicated enzyme purification fold and percentage yield of 59.3 and $12.6 \%$, and 4.76 and $47.0 \%$, respectively. 
The native molecular weight of the enzyme was estimated to be $58.0 \mathrm{KDa}$. The molecular weight of $\alpha$ amylase from Bacillus sp. was reported to vary between 50.0 and $60.0 \mathrm{KDa}$ with only a few exceptions (Smitha et al., 2019). Liu et al. (2008) found that the molecular weight of B. licheniformis, a thermostable $\alpha$ amylase was $53.13 \mathrm{KDa}$.

The Michaelis-Menten constant $\left(\mathrm{K}_{\mathrm{m}}\right.$ and $\left.\mathrm{V}_{\max }\right)$ values of the purified Bacillus subtilis $\mathrm{Y} 25$ a-amylase for hydrolysis of soluble starch were estimated to be $53.98 \pm 12.03 \mathrm{mg} / \mathrm{ml}$ and $314.10 \pm 23.30 \mathrm{Units} / \mathrm{mg}$ protein, respectively. Benjamin et al. (2013) stated that smaller values of $\mathrm{K}_{\mathrm{m}}$ observed for Bacillus spp. indicated that the enzyme and substrate are tightly bound and form the enzyme-substrate complex more quickly, thus more activity. The low $\mathrm{K}_{\mathrm{m}}$ value of purified Bacillus subtilis $\mathrm{Y} 25 \alpha$-amylase is an indication that the enzyme has the potential for effectiveness in the transformation of starch and starch-based substrates.

The purified $\alpha$-amylase from Bacillus subtilis Y25 displayed activity over a wide $\mathrm{pH}$ range of 4.5 to 9.0 but with optimum at 8.0. Anupama and Jayaraman (2011) recorded a similar $\mathrm{pH}$ of 8.0 for the enzyme from Bacillus aquimaris VITP4. $\alpha$-Amylases from most Bacillus sp. have optimum $\mathrm{pH}$ in the range 5.0 to 7.0 (Malhotra et al., 2000; Gupta et al., 2003; Sivaramakrishan et al., 2006). Yang et al. (2011) reported an alkaline $\alpha$-amylase with optimum pH of 9.0. The alkaline $\alpha$-amylase from Bacillus subtilis $\mathrm{Y} 25$, with optimum activity at $\mathrm{pH} 8.0$, has potential applications for hydrolyzing starch under high $\mathrm{pH}$ conditions in the starch and textile industries. It may also be of value as ingredients in detergent formulation for automatic dishwashers and laundries.

The purified $\alpha$-amylase from $B$. subtilis Y25 exhibited optimal activity at $60^{\circ} \mathrm{C}$. Similar results were obtained for $\alpha$-amylases from B. subtilis (Ozdemir et al., 2011) and B amyloliquefaciens P-001 (Deb et al., 2013). However, Yang et al. (2011) obtained an optimum temperature of $50^{\circ} \mathrm{C}$ for $\alpha$-amylase while Bakare $e t$ al. (2014) and Ozdemir et al. (2018) recorded optimal temperature of $70{ }^{\circ} \mathrm{C}$ for $\alpha$-amylases from Bacillus licheniformis $\mathrm{RD} 24$ and $B$. mojavensis $\mathrm{SO}-\mathrm{B} 11$, respectively. The enzyme exhibited appreciable thermal stability at temperatures up to $60^{\circ} \mathrm{C}$ for $50 \mathrm{~min}$. The relatively higher optimum temperature for activity and good thermal stability are properties of great significance for starch saccharification and may make the enzyme suitable for application to several biotechnological and industrial purposes such as in brewing and food processing.

The enzyme showed stability against calcium ion $\left(\mathrm{Ca}^{2+}\right)$, at $20 \mathrm{mM}$ concentration, but was slightly inhibited by sodium ion $(\mathrm{Na}+)$ and magnessium ion $\left(\mathrm{Mg}^{2+}\right)$, at the same concentration. Also, $\alpha$-amylase activity was significantly inhibited by EDTA. Similar results were reported by Hmidet et al. (2008) for $\alpha$ amylase from $B$. licheniformis NH1 and Yang et al. (2011) for alkaline $\alpha$-amylase from recombinant $B$. subtilis. However, $\mathrm{Ca}^{2+}$ activated $\alpha$-amylase from B. mojavensis SO-10 (Ozdemir et al., 2018). Lin et al. (1998) suggested that calcium ion acts as a stabilizer and activator for $\alpha$-amylase and that requirement for $\mathrm{Ca}^{2+}$ differ for different $\alpha$-amylases. EDTA produced an inhibitory effect on the enzyme activity. This suggests that the $\alpha$-amylase from $B$. subtilis $\mathrm{Y} 25$ is a metalloenzyme and that the enzyme contains metallic ions which are removed by the chelating agent, forming an active complex with EDTA and consequent loss of activity (Femi-Ola and Olowe, 2011). Similar results were reported for purified $\alpha$-amylase by several authors (Hmidet et al., 2008; Xie et al., 2014; Ozdemir et al., 2018). Chelating agents such as EDTA inactivate enzymes by either removing metal ions from the enzyme or by binding inside the enzyme as a ligand (Zeng et al., 2014).

\section{Conclusions}

$\alpha$-Amylase-producing Bacillus subtilis Y25 was isolated from deteriorating yam (Dioscorea rotundata) tubers. Enhanced $\alpha$-amylase production from the bacterium was achieved at $\mathrm{pH}$ and temperature conditions of 8.0 and $45^{\circ} \mathrm{C}$, respectively and with the use of starch and peptone as carbon and nitrogen sources, 


\section{8}

Aladejana OM et al. (2020). Not Sci Biol 12(1):154-171.

respectively. Purified $\alpha$-amylase from the isolate exhibited optimum activity at $\mathrm{pH} 8.0$ and temperature of 60 ${ }^{\circ} \mathrm{C}$. As a result of its activity and stability at high temperature and $\mathrm{pH}$, the enzyme has potentials for biotechnological applications for starch hydrolysis in textile industries and as an ingredient in detergents for dishwashers and launderers.

\section{Acknowledgements}

This research received no specific grant from any funding agency in the public, commercial, or not-forprofit sectors.

\section{Conflict of Interests}

The authors declare that there are no conflicts of interest related to this article.

\section{References}

Abdel-Fattah YR, Soliman NA, El-Toukhy NM, El-Gendi H, Ahmed RS (2012). Production, purification and characterization of thermostable $\alpha$-amilase produced by Bacilluslicheniformis isolate AI20. Journal of Chemistry 2013:1-11. https://doi.org/10.1155/2013/673173

Altschul SF, Gish W, Miller W, Myers EW, Lipman DJ (1990). Basic local alignment search tool. Journal of Molecular Biology 215(3):403-410. https://doi.org/10.1016/S0022-2836(05)80360-2

Anupama A, Jayarama G (2011). Detergent stable, halotolerant $\alpha$-amylase from Bacillus Aquimaris VITP4 exibits reversible unfolding. International Journal of Applied Biology and Pharmaceutical Technology 2(2):366-376.

Asgher M, Asad MJ, Rahman SU, Legge RL (2007). A thermostable $\alpha$-amylase from a moderately thermophilic Bacillus subtilis strain for starch processing. Journal of Food Engineering 79:950-955. https://doi.org/10.1016/j.jfoodeng.2005.12.053

Ayansina ADV, Adelaja AO, Mohammed SS (2017). Characterization of amylase from some Aspergillus and Bacillus species associated with cassava waste peels. Advances in Microbiology 7:280-292.

Azad MA, Bae JH, Kim JS, Lim JK, Song KS, Shin BS, Kim HR (2009). Isolation and characterization of a novel thermostable alpha-amylase from Korean pine seeds. Nature Biotechnology 26:143-149. bttps://dx.doi.org/10.1016/j.nbt.2009.09.006

Bakare MK, Omoboye OO, Adewale IO, Awojobi KO, Oyedeji O (2014). Purification and characterization of thermostable alpha-amylase by Bacillus licheniformis $\mathrm{RD} 24$ isolated from decayed refuse at Obafemi Awolowo University Campus, Ile-Ife, Nigeria. Frontiers of Biological and Life Sciences 2(4):74-84. http://dx.doi.10.12966/fbls.12.03.2014

Benjamin S, Smitha RB, Jisha VN, Pradeep S, Sajith S, Sreedevi S, Priji P, Unni KN, Sarath Josh MK (2013). A monograph on amylases from Bacillus spp. Advances in Biosciences and Biotechnology 4:227-241. doi:10.4236/abb.2013.42032

Bijttebier A, Goesaert H, Delcour JA (2008). Amylase action pattern on starch polymers. Biologia 63(6):989-999.

Bradford MM (1976). A rapid and sensitive method for the quantitation of microgram quantities of protein utilizing the principle of protein-dye binding. Analytical Biochemistry. 72:248-254 https://doi.org/10.1016/00032697(76)90527-3

Castro AM, Carvalho DF, Freire DMG, Castilho LR (2010). Economic analysis of the production of amylases and other hydrolases by Aspergillus awamori in solid-state fermentation of babassu cake. Enzyme Research 2010:1-9. http://dx.doi.org/10.4061/2010/576872

Das S, Singh S, Sharma V, Soni ML (2011). Biotechnological applications of industrially important amylase enzyme. International Journal of Pharma and BioSciences 2(1):486-496. 
Deb P, Talukdar SA, Mohsina K, Sarker PK, Sayem SA (2013). Production and partial characterization of extracellular amylase enzyme from Bacillus amyloliquefaciens P-001. Springerplus 2:154. http://dx.doi.org/10.1186/21931801-2-154.

Demirkan E, Sevgi T, Baskurt M (2017). Optimization of physical factors affecting the production of the $\alpha$-amylase from a newly isolated Bacillus sp. M10 strain. Karaelmas Fen ve Muhendislik Dergisi 7(1):23-30. http://dx.doi.org/10.7212\%2Fzkufbd.v1i1.458

El-Helow ER (2001). Identification and molecular characterization of a novel Bacillus strain capable of degrading tween-80. FEMS Microbiology Letters 196(2):119-122. https://doi.org/10.1111/j.1574-6968.2001.tb10551.x

El-Kady EM, Asker MS, Hassanein MS, Elmansy EA, El-Beih FM (2017). Optimization, production and partial purification of thermostable $\alpha$-amylase produced by marine bacterium Bacillus sp. NRC12017. International Journal of Pharmaceutical and Clinical Research 9(8):558-570. https://dx.doi.org/10.25258/ijpcr.v9i08.9581

Elmansy EA, Asker MS, El-Kady EM, Hassanein SM, El-Beih FM (2018). Production and optimization of $\alpha$-amylase from thermo-halophilic bacteria isolated from different local marine environments. Bulletin of the National Research Centre (2018) 42:31. http://dx.doi.org/101186/s42269-018-0033-2

Femi-Ola TO, Olowe BM (2011). Characterization of alpha amylase from Bacillus subtilis BS5 isolated from Amitermes evuncifer Silvestri. Research Journal of Microbiology 6:140-146. http://dx.doi.org/10.3923/jm.2011.140.146

Goes AP, Sheppard JD (1999). Effect of surfactants on $\alpha$-amylase production in a solid substrate fermentation process. Journal of Chemical Technology and Biotechnology 74:709-712.

Gangadharan D, Sivaramakrishnan S, Namboothiri KM, Pandey A (2006). Solid culturing of Bacillus amyloliquefaciens for $\alpha$-amylase production. Food Technology and Biotechnology 44(2):269-274.

Gomes I, Gomes J, Steiner W (2003). Highly thermostable amylase and pullulanase of the extreme thermophilic eubacterium Rhodothermus marinus: production and partial characterization. Bioresources and Technology 90:207-214.

Gupta R, Giras P, Mohapatra H, Goswami YK (2003). Microbial $\alpha$-amylase: a biotechnological perspective. Process Biochemistry 38(11):1599-1616.

Hmidet N, Bayoudh A, Berrin JG, Kanoun S (2008). Purification and biochemical characterization of a novel $\alpha$-amylase from Bacillus licheniformis NH1: Cloning, nucleotide sequence and expression of amyN gene in Escherichia coli. Process Biochemistry 43:499-510.

Khan JA, Yadav SK (2011). Production of $\alpha$-amylase by Aspergillus niger using cheaper substrates employing solid state fermentation. International Journal of Plant, Animal and Environmental Science 1(3):100-108.

Konsoula Z, Liakopoulou-Kyriakides M (2004). Hydrolysis of starches by the action of an alpha-amylase from Bacillus subtilis. Process Biochemistry 39(11):1745-1749.

Konsoula Z, Liakopoulou-Kyriakides M (2007). Coproduction of alpha-amylase and beta-galactosidase by Bacillus subtilis in complex organic substrates. Bioresources Technology 98:150-157.

Lin LL, Chyau C, Hsu WH (1998). Production and properties of a raw starch-degrading amylase from the thermophilic and alkaliphilic Bacillus sp. TS-23. Nature 6:68-74.

Liu Y, Lu F, Li Y, Yin X, Wang Y (2008). Acid stabilization of Bacillus licheniformis alpha amylase through mutations. Applied Microbiology and Biotechnology 45:259-267.

Malhotra R, Noorwez S, Satyanarayana T (2000). Production and partial characterization of thermostable and calcium independent $\alpha$-amylase of an extreme thermophile Bacillus thermooleovorans NP54. Letters in Applied Microbiology 31:378-384.

Matthew JJ, Vazhacharickal PJ, Sajeshkumar NK, John NK (2016). Comparative study of the activity of amylase produced by Aspergillus niger through solid state fermentation (SSF) using various starchy materials. Indian Journal of Plant Science 5:79-90.

Mitidieri S, Souza MAH, Schrank A, Vainstein MH (2006). Enzymatic detergent formulation containing amylase from Aspergillus niger. A comparative study with commercial detergent formulations. Bioresources Technology 97:1217-1224.

Mohammed MAA-Z, Shivayogeeshwar N, Gurumurthy DM, Rajeshwara AN (2011). Identification and characterization of novel halophilic Bacillus cereus Ms6: a source for extra cellular $\alpha$-amylase. Advances in Environmental Biology 5(5):992-999. 
170

Mukhtar H, Ikram UH (2012). Concomitant production of two proteases and alpha-amylase by a novel strain of Bacillus subtilis in a microprocessor-controlled bioreactor. Brazilian Journal of Microbiology 43:1072-1079.

NandLal Jyoti J, Sachan P (2016). Optimization of nitrogen source(s) for the growth and amylase production from Bacillus licheniformis JAR-26 under submerged fermentation. Indian Journal of Biology 3(2):127-132.

Omemu AM, Akpan I, Bankole MO, Teniola OD (2005). Hydrolysis of raw tuber starches by amylase of Aspergillus niger AM 07 isolated from soil. African Journal of Biotechnology 4:19-25.

Omoboye OO, Bakare MK, Adewale IO, Oyedeji O (2014). Molecular identification and amylolytic potential of a thermophilic bacteria species from refuse dump in Ile-Ife, Nigeria. International Journal of Biological Research 2(2):134-139.

Ozdemir S, Matpan F, Guven K, Baysal Z (2011). Production and characterisation of partially purified extracellular thermostable $\alpha$-amylase by Bacillus subtilis in submerged fermentation (SmF). Preparative Biochemistry and Biotechnology 41:365-381.

Ozdemir S, Fincan SA, Karakaya A, Enez B (2018). A novel raw starch hydrolysing thermostable $\alpha$-amylase produced by newly isolated Bacillus mojavensis SO-10: purification, characterization and usage in starch industries. Brazilian Archives of Biology and Technology 61: e18160399. http://dx.doi.org/10.1590/1678-4324-2018160399

Pandey A, Nigam P, Soccol CR, Soccol VT, Singh D, Mohan R (2000). Advances in microbial amylases. Biotechnology and Applied Biochemistry 31:135-152.

Prakash B, Vidyasagar M, Madhukumar MS, Muralikrishna G, Sreeramulu K (2009). Production, purification and characterization of the extremely halotolerant, thermostable and alkali-stable $\alpha$-amylases from Chromohalobacter sp. TVSP 101. Process Biochemistry 44:210-215. https://doi.org/10.1016/j.procbio.2008.10.013

Reddy NS, Nimmagada A, Sambasiva Rao KRS (2003). An overview of the microbial $\alpha$-amylase family. African Journal of Biotechnology 2:645-648.

Saxena L, Iyer BK, Ananthanarayan L (2007). Tree phase partitioning as a novel method for purification of ragi (Eleusine coracana) bifunctional amylase/protease inhibitor. Process Biochemistry 42:491-495.

Shalini S, Solanki MK (2014). Optimization of thermostable alpha-amylase production via mix agricultural-residues and Bacillus amyloliquefaciens. Notulae Scientia Biologicae 6(1):105-111.

Singh P, Gupta P, Singh R, Sharma R (2012). Factors affecting alpha amylase production on submerged fermentation by Bacillus sp. International Journal of Pharmaceutical and Life Sciences 3(12):2243-2246.

Singh V, Sharma R, Sharma P (2015). Isolation, screening and optimization of amylase producing Bacillus sp. from soil. Asian Pacific Journal of Health Science 2(3):86-93.

Singh AM, Latha BV, Chethankumar M, Kumar BYS (2016). A comparative study on fungal (Aspergillus niger) amylase and elephant foot yam (Amorphophallus campanulatus) amylase with yam starch as substrate. International Journal of Applied Research 2:1006-1010.

Sivaramakrishnan S, Gangadharan D, Nampoothiri M (2006). $\alpha$-Amylases from microbial sources. Food Technology and Biotechnology 44:173-184.

Somogyi M (1952). Notes on sugar determination. Journal of Biological Chemistry 194:19-21.

Smitha RB, Benjamin S, Prakashkumar R (2019). Fermentation strategies for the production of $\alpha$-amylase and $\delta$ endotoxin from Bacillus thuringiensis subsp. Kurstaki. Avid Science Monograph Series 1(192):37.

Souza PM, Magalhaes PO (2010). Applications of microbial amylases in industry - a review. Brazilian Journal of Microbiology 41:850-861.

Tamura K, Stecher G, Peterson D, Filipski A, Kumar S (2013). MEGA 6: molecular evolutionary genetics analysis version 6.0. Molecular Biology and Evolution 30(12):2725-2729. http://dx.doi.10.1093/molbev/mst197

Wanderley KJ, Torres FA, Moraes LM, Ulhoa CJ (2004). Biochemical characterization of alpha-amylase from the yeast Cryptococcus flavus. FEMS Microbiology Letters 231:165-169.

Xie F, Quan S, Liu D, Ma H, Li F, Zhou F, Chen G (2014). Purification and characterization of a novel $\alpha$-amylase from a newly isolated Bacillus methylotrophicus strain P11-2. Process Biochemistry 49:47-53.

Yang H, Liu L, Li J, Du G, Chen J (2011). Heterologous expression, biochemical characterization, and overproduction of alkaline $\alpha$-amylase from Bacillus alcalophilus in Bacillus subtilis. Microbial Cell Factories 10:77. http://dx.doi:10.1186/1475-2859-10-77 
Zeng J, Gao X, Dai Z, Tang B, Tang XF (2014). Effects of metal ions on stability and activity of hyperthermophilic pyrolysin and further stabilization of this enzyme by modification of a Ca2+-binding site. Applied and Environmental Microbiology 80(9):2763-2772. http://dx.doi:10.1128/AEM.00006-14

OPEN ACCESS

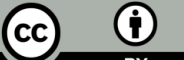

The journal offers free, immediate, and unrestricted access to peer-reviewed research and scholarly work, due SHST supports to increase the visibility, accessibility and reputation of the researchers, regardless of geography and their budgets. Users are allowed to read, download, copy, distribute, print, search, or link to the full texts of the articles, or use them for any other lawful purpose, without asking prior permission from the publisher or the author.

License - Articles published in Notulae Scientia Biologicae are Open-Access, distributed under the terms and conditions of the Creative Commons Attribution (CC BY 4.0) License.

(C) Articles by the authors; SHST, Cluj-Napoca, Romania. The journal allows the author(s) to hold the copyright/to retain publishing rights without restriction. 